Livestock Production and Land Use in Hills and Uplands

Occasional Publication No. 18 - British Society of Animal Production 1994

edited by T. L. J. Lawrence, D. S. Parker and P. Rowlinson

\title{
Research at Bronydd Mawr
}

\author{
J. M. M. Munro
}

AFRC Institute of Grassland and Environmental Research and the Macaulay Land Use Research Institute, Bronydd Mawr, Trecastle, Brecon LD3 8RD

\section{Background}

Bronydd Mawr Research Centre was established in 1983 to investigate future land use options in the less favoured areas, which cover $80 \%$ of the agricultural land in Wales. It is located in Powys, the county with the highest proportion of upland in England and Wales and, as a consequence of grassland improvement, the most intensive stocking of sheep and beef cattle in the United Kingdom (UK).

The farm now covers 230 ha between 250 and $400 \mathrm{~m}$ above sea level in the Brecon Beacons. Average annual rainfall is $1500 \mathrm{~mm}$, temperature $7.5^{\circ} \mathrm{C}$ and windspeed $15 \mathrm{~km} / \mathrm{h}$. The soils are mainly brown earths and gleys derived from Old Red Sandstone. Most of the area is in permanent pasture, reseeded over the past 25 years, with 40 ha of semi-natural rough grazing ( 8 ha of SSSI status) and woodland. Additional grazing is provided by an adjoining military training area and common. Nearly 1900 Brecknock Hill Cheviot and Beulah Speckled Face ewes and 60 Welsh Black, Hereford cross and Aberdeen Angus cross Friesian cows and their progeny are available for use in the pasture, animal, systems and land use research programme.

\section{Initial research}

Early studies concentrated on improving the efficiency of livestock production through the development of sward management guidelines. Research by Institute of Grassland and Environmental Research (IGER) and Macaulay Land Use Research Institute (MLURI) has provided clear height recommendations for upland sheep grazing improved pastures, particularly during the crucial mating, lactation and post-weaning periods. In August and September, for example, lambs grazing $4-\mathrm{cm}$ swards gained only $55 \mathrm{~g}$ live weight per day compared with $154 \mathrm{~g}$ on $7 \mathrm{~cm}$ and $216 \mathrm{~g}$ on $10 \mathrm{~cm}$. At Bronydd Mawr the effect of sward height has also been studied in relation to cow and calf performance.

A second major area has been the study of the value of pasture plant breeding in the uplands. New ryegrass and white clover varieties from IGER have been evaluated for important characteristics including winter hardiness and spring growth, compatibility and persistency. The facilities at Bronydd Mawr have also allowed two large-scale comparisons of sheep production. Over 6 years, swards of Aurora, a very early heading perennial ryegrass based on Swiss alpine material, produced proportionately 0.11 more, and Meltra, a Belgian tetraploid, 0.13 more than the old Aberystwyth variety, S23, because of better spring growth, nutritive value and clover content. A further trial has shown 0.14 higher lamb output over 3 years from S184 white clover compared with Huia, the New Zealand variety most widely used in the UK.

\section{Current research}

Earlier sheep systems studies examined the effect of ewe breed and prolificacy, fertilizer level and stocking rate on lamb output and food selfsufficiency. Research is now focused on lower input systems based on white clover. Ewe and lamb performance, silage production, concentrate inputs and economic returns are being compared with contrasting fertilizer regimes (200 and $50 \mathrm{~kg} \mathrm{~N}$ per ha per annum) and stocking rates (18, 15, 12 and 9 Beulah ewes and Suffolk cross lambs per ha). Over the first 3 years, little difference has been noted in gross margins before subsidies from the different systems, silage production at the lower stocking rates compensating for reduced lamb output.

Other research includes studies of the influence of different animal species on sward conditions, diet selection and performance. Where cows and calves grazed from May to July the subsequent growth rate of weaned lambs was $23 \%$ higher than where ewes and lambs had grazed. The main factor was a higher clover content in the sward after cattle $(13.9 v .5 .7 \%)$.

Long-term studies include work on the livestock production and environmental consequences of extensification. Bronydd Mawr is also one of the main sites in the UK National Agroforestry Network. 